\title{
Equilibria and geothermometry in hot alkaline waters from granites of $\mathrm{S}$. W. Bulgaria
}

\author{
Gil Michard $^{1}$, Bernard Sanjuan ${ }^{1}$, Annie Criaud ${ }^{2}$, Christian Fouillac ${ }^{2}$, \\ Elka N. Pentcheva ${ }^{3}$, Peter S. Petrov ${ }^{3}$ and Rumiana Alexieva ${ }^{3}$ \\ Laboratoire de Géochimie des Eaux (LA 196), Université Paris 7, F-75251 Paris Cédex 05, France ${ }^{1}$, \\ B. R. G. M., BP 6009, F-45060 Orleans Cédex, France ${ }^{2}$ et Institut de Géologie, \\ Académie des Sciences de Bulgarie, Sofia 1113, Bulgaria $^{3}$
}

(Received July 21, 1985: Accepted January 30, 1986)

\begin{abstract}
Sixteen hot alkaline waters from geothermal drillholes in S. W. Bulgaria have been studied. Nine of them are in approximate equilibrium with chalcedony, albite, adularia, calcite, kaolinite, and lowtemperature calcium zeolite at a temperature close to the outflow temperature. The others are in equilibrium with calcite and kaolinite and oversaturated with albite, chalcedony and adularia at the outflow temperature. Calculations of the evolution of chemical species due to the cooling indicate that equilibrium with these minerals is established at a temperature close to the temperature derived from the chemical geothermometers.

$\mathrm{Na} / \mathrm{K}, \mathrm{Na}-\mathrm{K} \cdot \mathrm{Ca}(\beta=4 / 3)$ and chalcedony (or quartz) geothermometers give satisfactory results in the low temperature range $40-140^{\circ} \mathrm{C}$.

Results obtained corroborate the model previously presented by Michard and Fouillac (1980) for alkaline hot waters.
\end{abstract}

\section{INTRODUCTION}

Twenty-five hot waters were sampled from boreholes drilled in to geothermal reservoirs in the S. W. of Bulgaria (Fig. 1). Of these waters, 16 are high in $\mathrm{pH}$, and low in salinity. We previously referred to these waters as alkaline waters (Michard and Roekens, 1983). Discharge is very large (up to $30 \mathrm{l} / \mathrm{s}$ ) and the outlet temperatures are close to the bottom temperatures.

Outflow temperature, $\mathrm{pH}$ and total dissolved solids are highly variable from a well to another and this set of waters provide a unique sequence for discussing equilibrium achievement between rocks and water at rather low temperatures $\left(40-140^{\circ} \mathrm{C}\right)$.

\section{SUMMARY OF GEOLOGY}

Thermal waters from Rila, Pirin, and Rodope mountains in S. W. Bulgaria are related to fault zones. Main reservoirs are located in faulted Paleozoic batholiths. These granites intruded Precambrian metamorphic rocks (Pentcheva and Petrov, 1969). Granitic massifs are divided by grabens (Struma and Mesta Valleys) filled with Tertiary and Quaternary sediments. Evidences of Ancient volcanic activities are common in these valleys (andesites from Mesta Valley; trachyandesites from Struma Valley; late Pliocene trachyandesites near Kojuh (Petrov, 1960)).

Thermal waters of the Velingrad area (Nos. 21 to 25) issue from granites and gneisses of the West Rodope mountains. Near Sofia, some hot springs are related to diorites (Zeleznica) or to andesites (Sofia, Gorna Banja).

\section{Sampling and Analytical Techniques}

Sampling and analytical techniques are described in detail by Boulégue et al. (1977, 1979). Water samples were collected in polyethylene flasks, washed with high purity grade nitric acid, and rinsed four times with deionized water. They were then filtered in the field 


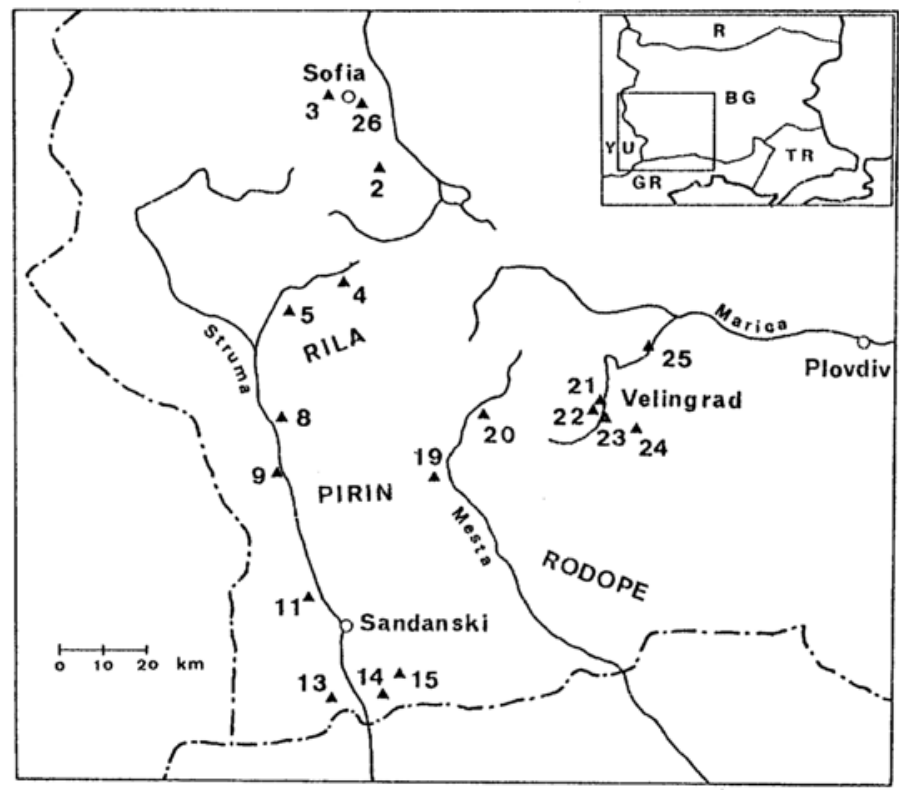

Fig. 1. Map of the studied area, the numbers indicating thermal wells. 2: Zeleznica, 3: Gorna Banja, 4: Sapareva Banja, 5: Slatino, 8: Blagoevgrad, 9: Simitli, 11: Breznica, 13: Kojuh, 14: Levunovo, 15: Hotovo, 19: Banja Razlog, 20: Jakoruda, 21: Draginovo, 22: Ladzene, 23: Cepino, 24: Rakotovo, 25: Varvara, 26: Sofia.

through "Sartorius" filters of $0.1 \mu \mathrm{m}$ pore diameter. The filtrate was divided into three parts: 1) $50 \mathrm{ml}$ was acidified with 10 drops of "Suprapur" (Merck) hydrochloric acid, 2) $10 \mathrm{ml}$ was diluted 10 times with deionized water, and 3 ) the rest was stored without any treatment.

Samples for analyses of major elements were stored in polyethylene flasks, samples for trace elements in PTFE flasks.

The $\mathrm{pH}$ was measured with an Ingold electrode and a Knick pH meter. The apparatus was calibrated against two buffers (6.81 and 9.18 at $25^{\circ} \mathrm{C}$ in sealed ampoules). Flasks with buffers were inserted in the outflowing water to equilibrate their temperatures. $\mathrm{A}$ pH of buffer vs. temperature curve is used to determine the $\mathrm{pH}$ of buffer at outflow temperature. The $\mathrm{pH}$ of the outflowing water was measured in sealed tubes to avoid any gas exchange.

Sulfide was titrated in the field with mercuric chloride solution, using a $\mathrm{S}^{2-}$ specific electrode (Ingold) and a double junction reference electrode.

Alkalinity was titrated in the field at the temperature of outflowing water.
Cations are measured in our laboratory in Paris by flame atomic absorption $(\mathrm{Na}, \mathrm{Ca}, \mathrm{Mg}$ ), by flame emission $(\mathrm{K}, \mathrm{Li})$, or by flameless atomic absorption (Al) using a Hitachi 180-70 spectrophotometer. $\mathrm{Cl}^{-}$and $\mathrm{SO}_{4}{ }^{2-}$ by ion chromatography (Vydac 213), $\mathrm{SiO}_{2}$ by heptamolybdate colorimetry and $\mathrm{F}^{-}$by direct measurement with a specific ion electrode (Ingold).

Analytical data were processed with EQUEAU and VARTEMP computer programs initiated by Fouillac (unpublished) and adapted for an HP 86B microcomputer. The programs are available from the senior author. Analytical results are shown in Table 1.

\section{Dis CUSSION}

Bulgarian alkaline hot waters are similar to Pyrénées and Corsica hot waters (Michard and Fouillac, 1980).

The main characteristics are: 1) High $\mathrm{pH}$ : up to 9.7 at $40^{\circ} \mathrm{C}$ and 8.4 at $97^{\circ} \mathrm{C}, 2$ ) Sodium is the major cation, and 3) Magnesium concentrations are very low $\left(10^{-6} \mathrm{M}\right)$.

Contrary to S. France waters, sulfate con- 


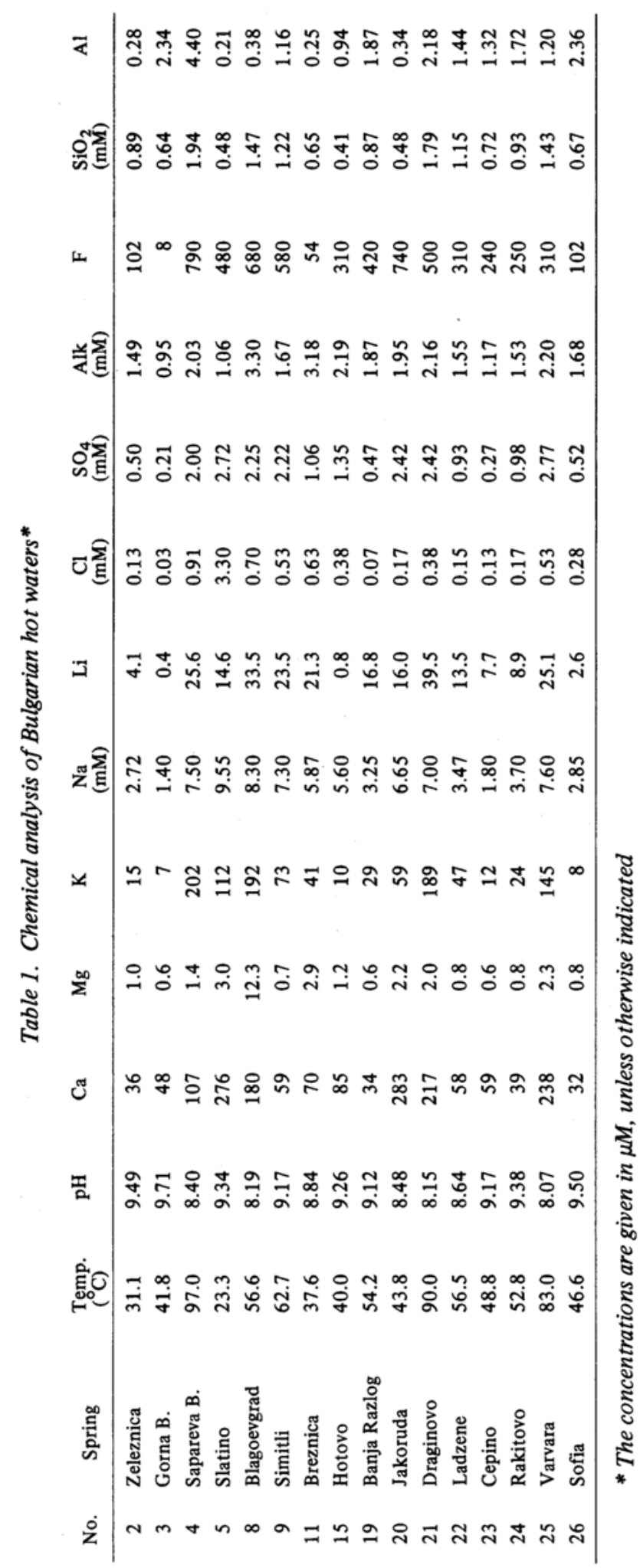


centrations are generally higher than chloride concentrations.

A relationship between $\mathrm{pH}$ and temperature is observed. In Pyrénées and Corsica, $\mathrm{pH}$ decreases with increasing temperature by about $0.13 \mathrm{pH}$ unit for $10^{\circ} \mathrm{C}$. This trend is roughly observed in Bulgaria, although it depends also on the sulphate content. Some waters do not follow this general trend: especially samples 8 and 20 and to a lesser extent samples 11 and 22 .

This can be related to mixing either with superficial water (e.g., for samples 8 which contains more magnesium than the other waters) or with $\mathrm{CO}_{2}$ invasion (as discussed later).

Alkaline waters are widely distributed in granites. In Europe, we find them in Spanish (Vuataz et al., 1985) and French Pyrénées (Michard and Fouillac, 1980), in Vosges (Fritz, 1981), in Swiss (Vuataz, 1982), Italian (Fancelli and Nuti, 1978) and French Alps (Grimaud, 1986), in Portugal (De Carvalho, 1955) and in Corsica (Michard and Fouillac, 1980). They seem to be present also in United States and in Japan; some preliminary results can be found in general surveys (Brooks et al., 1978; Sumi, 1975). Typical alkaline waters occur also in Tibet (Grimaud et al., 1985). Alkaline waters are also present in basaltic areas, e.g., Iceland (Arnorsson et al., 1983).

From studies of natural springs in Pyrénées and Corsica, we have already presented a model of alkaline hot waters (Michard and Fouillac, 1980; Michard and Roekens, 1983). Waters studied flow out at a temperature definitively lower than reservoir temperature. Some basic assumptions of the model - the only changes in the bulk chemical composition concern aluminum and silica which are continuously in equilibrium with kaolinite - cannot be verified because drillholes are not available in France. This study on Bulgarian drillholes is an attempt to check some of the assumptions of the model.

The chemistry of hot waters may be disturbed by drilling operations. However, it is generally claimed that after a period of one month to one year, stability of chemical composition is reached (Mahon, 1975). This composi- tion corresponds to that of the highest permeability level. The only process which can modify chemical composition is boiling. This situation is encountered where extensive production takes place in low permeability zones with high heat flow. These conditions are obviously not fulfilled in Bulgarian systems, where permeabilites are high and heat flow is moderate. Most holes were drilled at least 10 years ago; we can therefore consider that the chemistry of fluid samples is representative of the chemistry at deep levels.

Processes controlling concentrations of major elements

Silica: Concentrations of species $\mathrm{H}_{4} \mathrm{SiO}_{4}$ were calculated from total dissolved silica using temperature and $\mathrm{pH}$ of outflowing water. Of the 16 springs studied, eight lie close to the chalcedony solubility curve; the other springs are supersaturated with chalcedony (Fig. 2). In this temperature range, chalcedony is considered to be a good geothermometer (Arnorsson, 1975).

The saturation index shows that the eight waters (named hereafter Group I) flow out at a temperature close to the equilibrated one in the reservoir.

The other waters (Group II) are supersaturated with chalcedony at the outflow temperature. It is possible that they were in equilibrium with chalcedony in the reservoir,

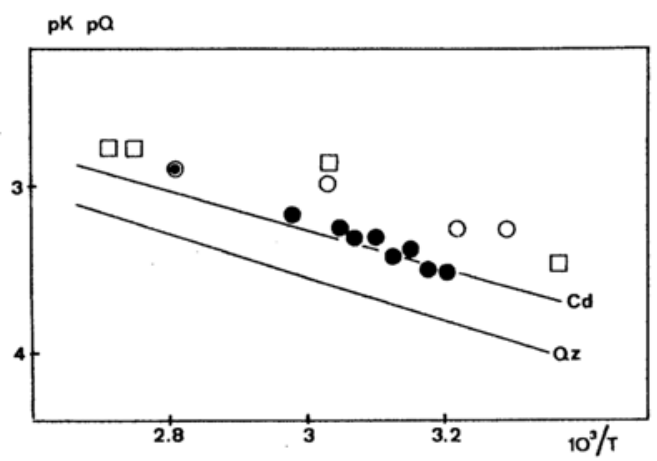

Fig. 2. $\quad p K(=-\log$ solubility, shown by solid line) and $p Q(=-\log$ observed concentration, shown by symbols) vs. temperature. - : Group I waters, $\bigcirc, \square:$ Group II waters, $\bullet$ : Varvara water. 
but they cooled down approaching the surface. Varvara spring (No. 25, outflow temperature $83^{\circ} \mathrm{C}$ ) lies between the two groups.

We cannot preclude an equilibrium at deep levels with quartz, at least for some samples: in this case, the temperature at deep levels would be about $30^{\circ} \mathrm{C}$ higher than those calculated on the assumption of equilibrium with chalcedony. This point will be further discussed in the following section.

Some observed supersaturations can be associated with a secondary change in $\mathrm{pH}$. Any error in $\mathrm{pH}$ measurement has a very small influence on the calculated deviations from equilibrium. For example, if $\mathrm{pH}$ values of samples 20 and 8 are 1 unit higher than measured ones, then the saturation index for chalcedony changes from +0.11 to -0.07 for spring 20 and from +0.46 to +0.27 for spring 8 . This does not change the conclusion that spring 20 is nearly in equilibrium with chalcedony and that spring 8 is supersaturated with it.

In the following sections, we will often distinguish between waters flowing out at temperatures near chalcedony equilibrium (Group I) and those supersaturated with the mineral (Group II).

Aluminum: Concentrations of dissolved aluminum are related to both temperature and $\mathrm{pH}$. Aluminum concentrations increase with increasing $\mathrm{pH}$ and temperature. At $\mathrm{pH}$ and temperature of the waters studied, $\mathrm{Al}(\mathrm{OH})_{4}{ }^{-}$is by far dominant Al species (Couturier et al., 1984; Nazarenko and Nevskaia, 1969).

All waters are supersaturated with gibbsite, but they are close to equilibrium with kaolinite and pyrophyllite (Fig. 3). Equilibrium with kaolinite seems to be attained in many waters: the saturation index IS (IS $\tilde{n} \log \left(\mathrm{IAP} / \mathrm{K}_{\mathrm{S}}\right.$, where IAP is the ionic activity product and $\mathrm{K}_{\mathrm{S}}$ the solubility product for the reaction: $0.5 \mathrm{Al}_{2} \mathrm{Si}_{2} \mathrm{O}_{5}$ $\left.(\mathrm{OH})_{4}+3.5 \mathrm{H}_{2} \mathrm{O}=\mathrm{Al}(\mathrm{OH})_{4}^{-}+\mathrm{Si}(\mathrm{OH})_{4}+\mathrm{H}^{+}\right)$ is in the range from -0.5 to +0.4 . This index is very sensitive to $\mathrm{pH}$ change and the greatest supersaturation is observed for mixed water (spring 8).

An important point is that both groups of

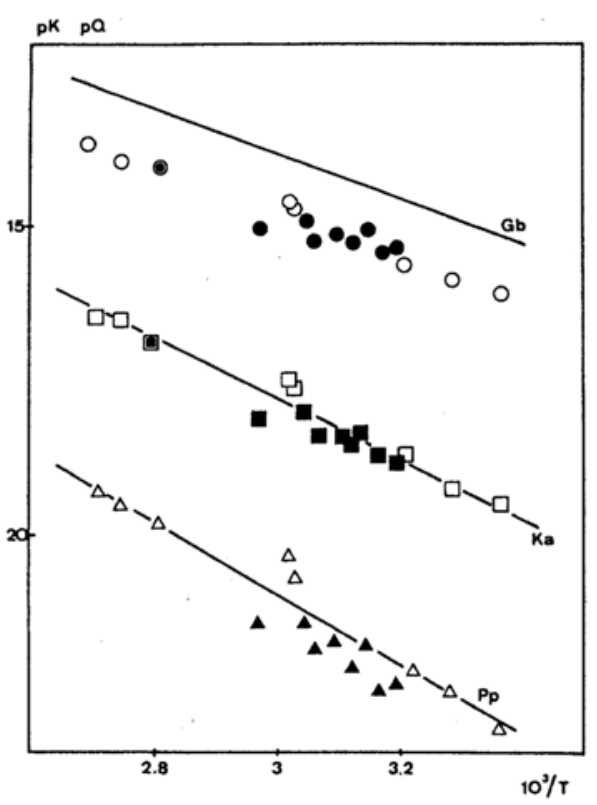

Fig. 3. $p K(=-\log$ solubility product, shown by solid lines) and $p Q(=-\log$ ion activity product, shown by symbols) vs. temperature for aluminum minerals: gibbsite $(G b)$, kaolinite $(\mathrm{Ka})$ and pyrophyllite $(\mathrm{Pp})$. $\bullet,-, \Delta$ : Group I waters, ○, ૨, $\triangle$ : Group II waters, and ๑, $₫$ : Varvara water.

cooled water (Group II) and of waters flowing out at temperatures close to those at deep levels (Group I) are roughly in equilibrium with kaolinite. This is consistent with the assumption of equilibrium with kaolinite in the reservoir and its precipitation during the cooling of water.

Equilibrium calculations with pyrophyllite have also been performed; pyrophyllite is the aluminous end member of the smectite series and it is often used to estimate saturation of waters with smectites (Helgeson et al., 1978). Many waters, especially cooled waters, are close to equilibrium with pyrophyllite. Nevertheless, the scattering of IS is greater for pyrophyllite than for kaolinite. In Pyrénées and Corsica, approximate equilibrium with kaolinite was observed and evidence for kaolinite deposition in pipes were presented by Boulègue et al. (1981).

Sodium: From sodium, aluminum and silica speciation, we are able to calculate saturation indices with respect to albite and analcime. 


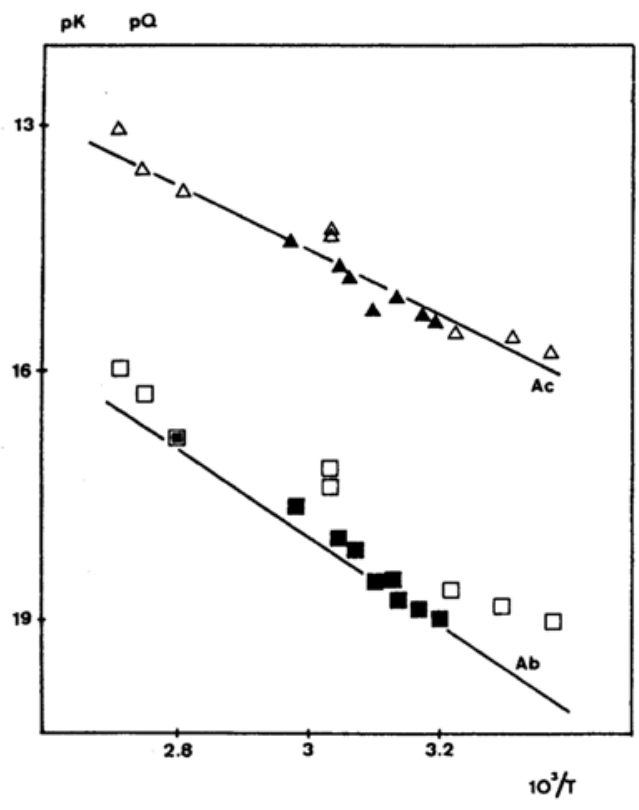

Fig. 4. $p K$ and $p Q$ vs. temperature for sodium minerals: albite $(A b)$ and analcime $(A c) . \backsim, \mathbf{4}$ : Group I waters, $\square, \Delta$ : Group II waters, and $\Xi$ : Varvara water.

In Fig. 4, we plot IAP for albite and analcime and the calculated $K_{S}$ values of these minerals vs. outflow temperature. Thermodynamic data are from Michard (1983).

Cooled waters (Group II) are significantly supersaturated with albite, but hot waters (Group I) are very close to saturation (IS in the range of $0.00-0.34$ ). All waters of Groups I and II are close to saturation with analcime. This behavior of analcime will be further discussed in the section on modelling.

Potassium: In the same way as above, equilibria were calculated with respect to adularia. As pointed out by Helgeson et al. (1978), thermodynamical data for adularia are very close to those for microcline. We use microcline data to calculate $\mathrm{K}_{\mathrm{s}}$ plotted in Fig. 5, together with IAP.

Once more, waters from Group I are nearly in equilibrium (with IS of -0.23 to 0.45 ), whereas those from Group II are distinctly supersaturated (with IS of 0.80 to 1.50 ) with adularia.

Muscovite, known as a high-temperature mineral, is roughly in equilibrium with Group I waters; muscovite is the potassic end member of

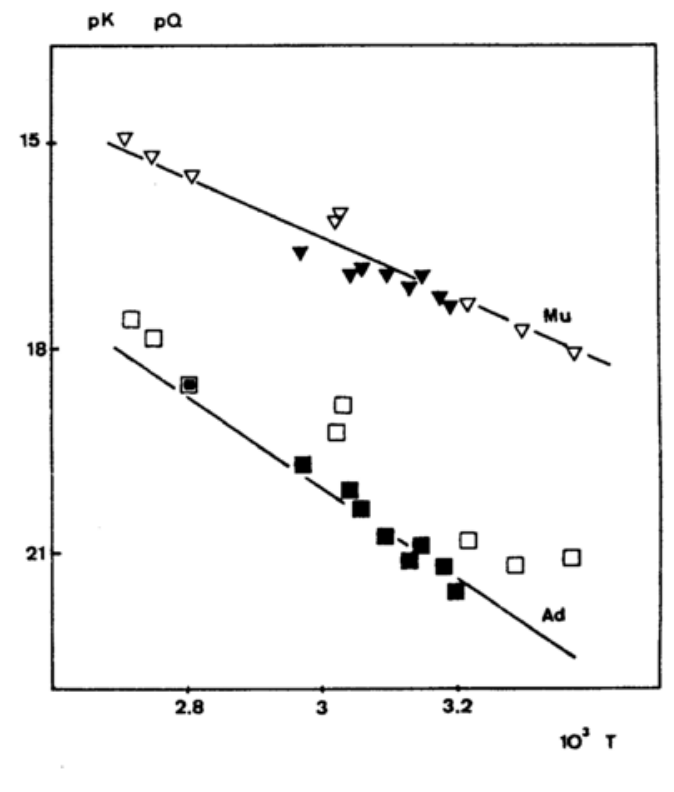

Fig. 5. $p K$ and $p Q$ vs. temperature for potassium minerals: adularia (Ad) and muscovite (Mu). Symbols as in Figure 4.

the series of illitic clays: our data suggest an equilibrium with this kind of clay minerals.

Calcium and carbonate: All Bulgarian waters are slightly supersaturated with calcite (IS from +0.05 to +0.45 ). Although such supersaturation has been observed in many cases, it is not easy to explain it. Occurrence of magnesian calcites is not probable in these waters, because they are low in magnesium.

As previously discussed (Arnorsson et al., 1983; Michard, 1985), an approximate equilibrium with calcite will control either calcium or carbonate concentration. In places where high $\mathrm{CO}_{2}$ fluxes are present, e.g., in French Massif Central (Michard et al., 1981), $\mathrm{p}\left(\mathrm{CO}_{2}\right)$ is an external factor, and is generally high ( $>1$ atm.). Calcite solubility controls calcium concentrations. In these areas, there are some lines of evidence of mantle contribution to the isotopic composition of helium (O'Nions et al., 1985).

On the contrary, in Pyrénées and Corsica (Michard and Fouillac, 1980) or in Iceland (Arnorsson et al., 1983), calculated $\mathrm{p}\left(\mathrm{CO}_{2}\right)$ is related to the temperature at deep levels. In these regions, helium is mainly of crustal origin 
$\log \mathrm{pCO}_{2}$

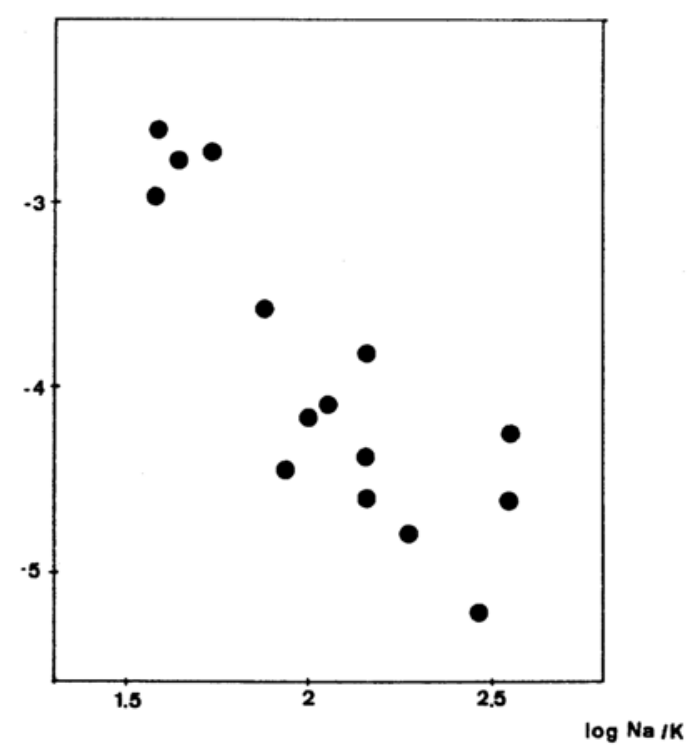

Fig. 6. Relationship between $p\left(\mathrm{CO}_{2}\right)$ calculated at outflow temperature and $\log (\mathrm{Na} / \mathrm{K})$.

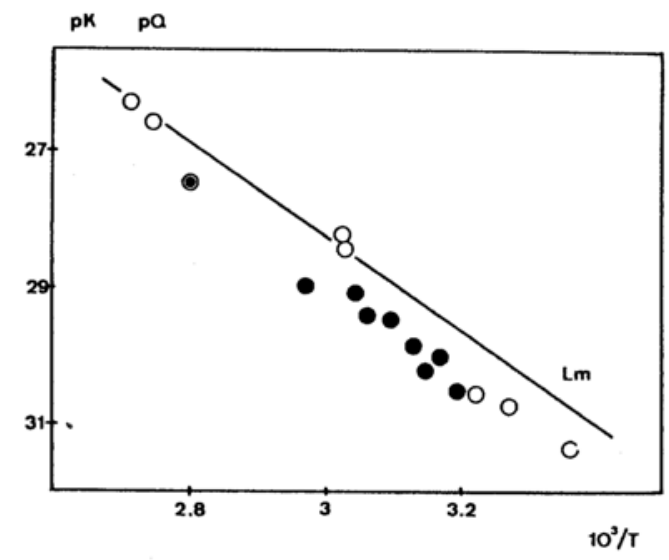

Fig. 7. $p K$ and $p Q$ vs. temperature for laumontite $(\mathrm{Lm})$. -: Group I waters, ०: Group II waters, and ०: Varvara water.

(Oxburgh and O’Nions, 1984).

For Bulgarian waters too, an approximate relationship between $\mathrm{p}\left(\mathrm{CO}_{2}\right)$ and temperature derived from silica or $\mathrm{Na} / \mathrm{K}$ geothermometers is observed (Fig. 6). This suggests that $\mathrm{p}\left(\mathrm{CO}_{2}\right)$ is controlled by mineral equilibria and not by external conditions. At low temperatures, p $\left(\mathrm{CO}_{2}\right)$ is less than $10^{-4}$ atm.; some difficulties involved in $\mathrm{pH}$ measurements can be related to these low values far below atmospheric $\mathrm{p}\left(\mathrm{CO}_{2}\right)$.

$\mathrm{CO}_{2}$ invasion can occur especially when waters are carried over a long distance from the natural outflow to the sampling place. It is the case of springs 8,20 and 22 which supply waters for public baths, and the waters can be sampled only at taps after a long travel in pipes.

If $\mathrm{CO}_{2}$ is controlled by mineral equilibria including calcite, calcium will be controlled by another mineral, probably a calcium aluminosilicate.

Calcium alumino-silicates which can control calcium concentration are numerous and their thermodynamic properties are poorly known, or even unknown: zeolites (heulandite, stilbite, thomsonite, chabazite, laumontite), "pseudozeolite" (prehnite), clay minerals (montmorillonites), and epidotes (zoisite). Anorthite is known to be unstable between 0 and $300^{\circ} \mathrm{C}$ before all these minerals.

Saturation indices were calculated for laumontite, prehnite and zoisite. Solubility data are lacking for other zeolites and for montmorillonite. The indices for prehnite and zoisite are highly variable, whereas the waters from Group I exhibit an IS almost constant at -0.5 with laumontite. Maruyama et al. (1983) show that laumontite is less stable than heulandite or stilbite at low temperatures $\left(<100^{\circ} \mathrm{C}\right)$. It is then possible to consider that calcium is controlled by a low-temperature zeolite.

Magnesium: According to the very low amount of dissolved magnesium in alkaline waters, it is difficult to reveal the process which controls this element.

Waters from Bulgaria are strongly supersaturated with magnesium silicates: chrysotile, talc or clinochlore. This can be related either to incorrect thermodynamic data or to inaccurate values of dissolved magnesium in thermal waters, or to an equilibrium with a non-stoichiometric mineral. Magnesium content is largely affected by mixing with superficial water or secondary reactions associated with cooling.

For both cooled and uncooled waters, 


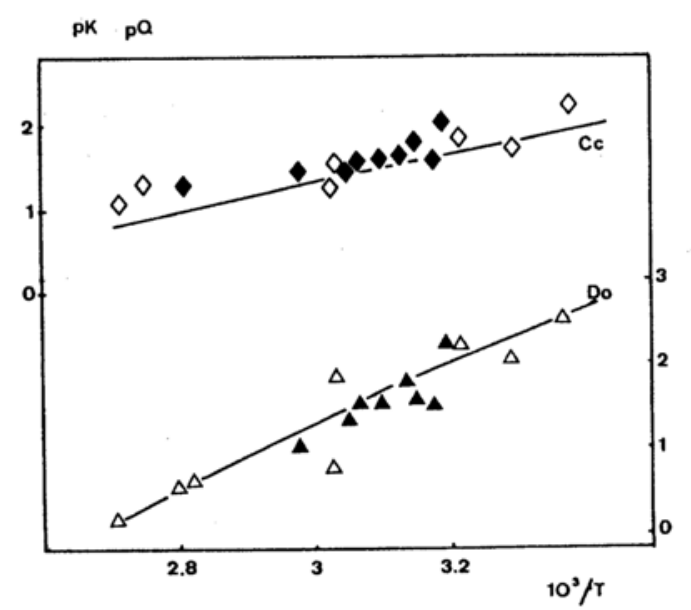

Fig. 8. $p K$ and $p Q$ vs. temperature for calcite $(C c)$ and

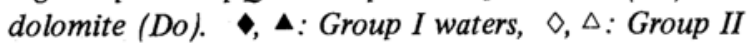
waters.

magnesium concentrations are roughly in equilibrium with ordered dolomite (Fig. 8). This does not necessarily mean that dolomite controls magnesium concentrations. For some waters in dolomitic reservoirs, magnesium is controlled by disordered dolomite and not by ordered dolomite (Bastide, 1985). Whatever the controlling mineral may be, however, magnesium concentrations in alkaline waters will be very low.

Other elements: Saturation indices are highly negative for gypsum and anhydrite. Sulfate ions are certainly not controlled by sulfate mineral solubility.

Fluorite is in equilibrium with some waters, but strongly undersaturated with the others.

Sulfide was detected only in 4 or 5 waters. Eh was measured, but its significance is ques- tionable (Morris and Stumm, 1967; Michard, 1967). We did not check any possible redox buffer for these waters.

\section{Geothermometry}

For this discussion, the two previously defined groups, i.e., Group I: waters flowing out at a temperature close to the temperature at deep levels, and Group II: waters cooled during ascent from reservoir to the surface, will be treated separately.

Group I: The classification into the groups was based on saturation with chalcedony. As previously stated, waters apparently saturated with chalcedony can be initially equilibrated with quartz at higher temperatures.

Tables 2 and 3 provide strong arguments for the hypothesis of equilibrium with chalcedony at a temperature close to the outflow one. In Table 2 are reported the temperatures calculated with different geothermometers: Chalcedony geothermometer (Truesdell, 1975); Sodiumpotassium geothermometer (White, 1965; Ellis, 1970), using either an empirical thermometric

Table 2. Geothermometry of Group I waters

\begin{tabular}{|c|c|c|c|c|c|}
\hline \multirow{2}{*}{ No. } & \multirow{2}{*}{$\begin{array}{l}\text { Outflow } \\
\text { temp. }\left({ }^{\circ} \mathrm{C}\right)\end{array}$} & \multicolumn{4}{|c|}{$\begin{array}{l}\text { temp. }\left({ }^{\circ} \mathrm{C}\right) \text { determined with different } \\
\text { geothermometers }\end{array}$} \\
\hline & & $\mathrm{Na} / \mathrm{K}$ & chalcedony & $\mathrm{Na} / \mathrm{Li}$ & $\begin{array}{c}\mathrm{Na}-\mathrm{K}-\mathrm{Ca} \\
(\beta=4 / 3)\end{array}$ \\
\hline 3 & 42 & 43 & 28 & -20 & 52 \\
\hline 9 & 63 & 68 & 67 & 70 & 61 \\
\hline 15 & 40 & 10 & 30 & -30 & 40 \\
\hline 19 & 54 & 66 & 57 & 100 & 83 \\
\hline 20 & 44 & 65 & 46 & 60 & 68 \\
\hline 23 & 49 & 52 & 50 & 90 & 41 \\
\hline 24 & 53 & 51 & 52 & 60 & 76 \\
\hline 26 & 46 & 21 & 39 & 19 & 46 \\
\hline
\end{tabular}

Table 3. Saturation indices of different minerals in Group I waters

\begin{tabular}{ccccccccc} 
No. & albite & analcime & chalcedony & calcite & dolomite & kaolinite & adularia & pyrophyllite \\
\hline 3 & 0.04 & -0.15 & -0.07 & 0.05 & -0.58 & -0.29 & 0.18 & -0.68 \\
9 & 0.34 & -0.03 & 0.11 & 0.23 & -0.24 & -0.60 & 0.51 & -0.72 \\
15 & 0.07 & -0.16 & -0.04 & 0.49 & 0.32 & -0.14 & -0.23 & -0.51 \\
19 & 0.34 & -0.02 & 0.11 & 0.11 & -0.85 & -0.08 & 0.56 & -0.25 \\
20 & 0.06 & -0.32 & 0.10 & 0.34 & -0.29 & 0.18 & 0.38 & -0.02 \\
23 & 0.00 & -0.36 & 0.09 & 0.15 & -0.44 & -0.10 & 0.15 & -0.30 \\
24 & 0.24 & -0.09 & 0.06 & 0.14 & -0.16 & -0.38 & 0.33 & -0.61 \\
25 & 0.10 & -0.13 & -0.03 & 0.17 & 0.00 & -0.21 & -0.08 & -0.56 \\
26 & 0.33 & -0.08 & 0.16 & 0.38 & 0.00 & 0.00 & 0.57 & -0.03 \\
\hline
\end{tabular}


relationship (Michard, 1979) or the relationship derived from thermodynamic data of albite and adularia; Sodium-lithium geothermometer (Fournier and Truesdell, 1973).

The temperatures derived from $\mathrm{Na}-\mathrm{K}-\mathrm{Ca}$ geothermometer $(\beta=1 / 3)$ are generally too high in this kind of waters. We will further discuss this point below and show that improved results are obtained with $\beta=4 / 3$.

On the contrary, $\mathrm{Na} / \mathrm{K}$ geothermometer, which is often adequate to these waters, gives values very close to both outflow and chalcedony temperatures. A marked exception is Hotovo spring, where $\mathrm{Na} / \mathrm{K}$ geothermometer gives a surprisingly low value.

The values calculated with $\mathrm{Na} / \mathrm{Li}$ ratios present some disagreement with those obtained from other geothermometers. This can be related to a poor accuracy of this geothermometer in this temperature range.

Table 3 reports saturation indices of Group I waters for different minerals. The table includes results on Varvara spring (No. 25), which is only slightly cooled. The general trend is that all waters are in close equilibrium with all these minerals.

Varvara water is slightly supersaturated with albite, adularia and chalcedony. This is also the case for Similti, Banya Razlog and Rakitovo waters. All these waters can be slightly cooled (by about $10-15^{\circ} \mathrm{C}$ ).

A low temperature calculated for Hotovo water is related to a slight undersaturation with adularia. It is noticeable that such a small undersaturation involves an important temperature difference; especially, temperature calculated with the empirical relationship differs more strongly from that obtained with thermodynamic data in this temperature range.

The general significance of calculated saturation indices is questionable. The accuracy of solubility products varies with minerals. For some "simple" minerals, such as chalcedony, quartz or calcite, the logarithm of solubility product is known with an accuracy of 0.01 or better. For others, solubility product depends on both crystallinity and particle size (Helgeson et al., 1978) and can vary over two orders of magnitude. Nevertheless, a close agreement of solubility products of well crystallized minerals with ionic activity product in geothermal alkaline waters was documented in basaltic area (Arnorsson et al., 1983). It is possible that the equilibration proceeds rapidly at high $\mathrm{pH}$ 's.

As no mineralogical description of the drillholes is available, it is not possible to ascertain that the minerals pertinent to equilibrium as assumed from IS calculations are effectively present and to discuss their crystallinity.

As ion concentrations vary from one water to another, by more than one order of magnitude (e.g., $\mathrm{K}, \mathrm{Al}$ and $\mathrm{H}$ ), and the solubility product in this temperature range $\left(40-85^{\circ} \mathrm{C}\right)$ varies over 2 orders of magnitude for minerals such as kaolinite or adularia, it is difficult to consider the constancy of IS at about zero to be fortuitous.

Group II: This group includes waters more or less cooled during the rise from the reservoir to the surface.

Chemical changes during the cooling were calculated with a simulation scheme previously developed in the Laboratoire de Géochimie des Eaux (Michard and Fouillac, 1980; Michard and Roekens, 1983). To put it briefly, this calculation assumes equilibria between some minerals and the solution. Previous discussion suggests that Bulgarian waters remain in equilibrium with kaolinite, dolomite and eventually with calcite during the cooling. Calculation starts from the chemical speciation at outflow temperature obtained by EQUEAU program and derives step by step a complete chemical speciation at any other temperature (VARTEMP program). Saturation indices for different minerals are also calculated at given temperature.

As shown in Fig. 9a and 9b, saturation indices for minerals such as adularia, albite, chalcedony or quartz, and occasionally laumontite converge to zero at the same temperature which is considered to be an equilibrium temperature.

Temperatures calculated by classical geothermometers are reported together with equili- 
I. S.

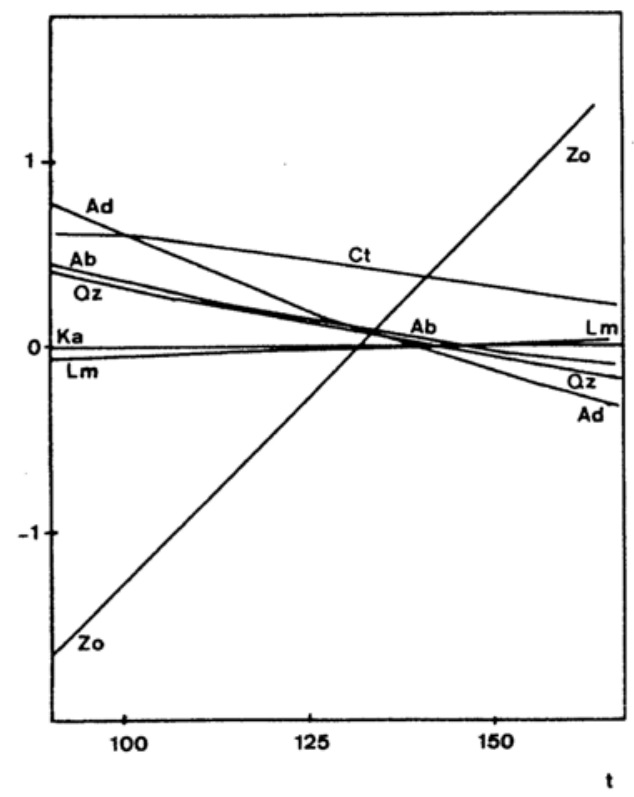

Fig. $9 a$
I.S.

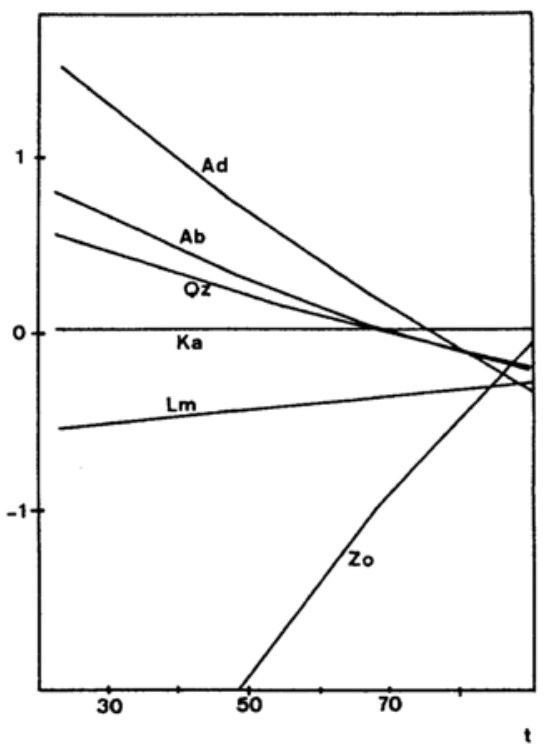

Fig. $9 b$

Fig. 9. Calculated saturation indices for different minerals vs. temperature: zoisite (Zo). chrysotile (Ct.). (a) Draginovo water, (b) Slatino water.

Table 4. Geothermometry of Group II waters

\begin{tabular}{|c|c|c|c|c|c|c|c|c|}
\hline \multirow{2}{*}{ No. } & \multicolumn{5}{|c|}{ temp. $\left({ }^{\circ} \mathrm{C}\right)$ determined with geothermometers } & \multicolumn{3}{|c|}{ temp. $\left({ }^{\circ} \mathrm{C}\right)$ obtained in the simulation* } \\
\hline & $\mathrm{Na} / \overline{\mathrm{K}}$ & chalcedony & quartz & $\mathrm{Na} / \mathrm{Li}$ & $\mathrm{Na}-\mathrm{K}-\mathrm{Ca}$ & albite & adularia & $\mathrm{SiO}_{2}{ }^{* *}$ \\
\hline 2 & 53 & 61 & 86 & 27 & 59 & 70 & 63 & 63 \\
\hline 4 & 130 & 110 & 138 & 80 & 139 & 155 & 145 & 145 \\
\hline 5 & 72 & 43 & 68 & 40 & 93 & 71 & 76 & 71 \\
\hline 8 & 124 & 100 & $131(115)^{* * *}$ & 87 & 123 & - & - & - \\
\hline 11 & 62 & 62 & 86 & 80 & 84 & 67 & 64 & 65 \\
\hline 21 & 133 & 112 & 139 & 91 & 116 & 145 & 139 & 141 \\
\hline 22 & 86 & 88 & 115 & 85 & 88 & - & - & - \\
\hline 25 & 106 & 100 & 127 & 78 & 104 & 110 & 107 & 102 \\
\hline
\end{tabular}

* Described in text.

** Quartz or chalcedony.

*** The value of $115^{\circ} \mathrm{C}$ corresponds to a calculated one with a corrected pH (see text).

brium temperatures obtained by simulation for adularia, albite, chalcedony or quartz in Table 4.

Concentrations of $\mathrm{H}_{4} \mathrm{SiO}_{4}$ increase slightly with temperature in simulations, first because the fraction of unionized silica increases with temperature, and secondly because kaolinite is increasingly soluble with temperature. Therefore the equilibrium temperature with quartz or chalcedony is always a little greater than the temperatures obtained with geothermometers. It appears that the waters from Sapareva Banja
(No. 4), Draginovo (No. 21) and also the waters from Slatino (No. 5) which outflow at only $23^{\circ} \mathrm{C}$, are equilibrated with quartz instead of chalcedony.

Due to the problems encountered in $\mathrm{pH}$ determinations, no attempt was made for simulation of Blagoevgrad water. The temperature derived from silica concentrations is rather sensitive to $\mathrm{pH}$. The $\mathrm{pH}$ decreases associated either with mixing with surface water or with $\mathrm{CO}_{2}$ invasion can give temperature overestimated 
by $20^{\circ} \mathrm{C}$. In this case, the quartz temperature will be about $115^{\circ} \mathrm{C}$, which is very close to the $\mathrm{Na} / \mathrm{K}$ temperature.

The four other waters are certainly equilibrated with chalcedony. Calculations show also that saturation indices for some minerals, such as analcime and laumontite, do not vary with temperature; therefore, as previously stated, the waters of both Groups I and II are in approximate saturation with analcime at outflow temperature.

$\mathrm{Na}-\mathrm{K}-\mathrm{Ca}$ relationships: As pointed out by Tonani (1980), the Na-K-Ca geothermometer of Fournier and Truesdell (1973) is an empirical relationship which is a combination of two independent geothermometers: the $\mathrm{Na} / \mathrm{K}$ ratio and the quantities $\mathrm{Ca}^{1 / 2} / \mathrm{Na}$ and $\mathrm{Ca}^{1 / 2} / \mathrm{K}$, which can be considered to be possible geothermometric relations.

$\mathrm{Ca}^{1 / 2} / \mathrm{K}$ produces a strong correlation with calculated or measured temperature at deep levels. The thermometric equation calculated from Bulgarian hot waters:

$$
\log \left(\mathrm{Ca}^{1 / 2} / \mathrm{K}\right)=1270 / \mathrm{T}-1.45
$$

is very similar to the equation derived from southern France and Icelandic waters (Michard and Roekens, 1983).

The above equation is consistent with those of $\mathrm{Na} / \mathrm{K}$ and $\mathrm{Na}-\mathrm{K}-\mathrm{Ca}(\beta=4 / 3)$ geothermometers. Even when the temperature at deep levels is significantly higher than $100^{\circ} \mathrm{C}$, Fournier and Truesdell's relationship gives satisfactory results, if $\beta$ is taken as $4 / 3$. This result has been pointed out by Vandelannoote (1984) for Pyrenean waters. In their compilation, Fournier and Truesdell have considered only very few waters of this type (mainly Icelandic waters); as the geothermometer has no definite theoretical basis, it is rather difficult to related the change in $\beta$ with that in minerals controlling Ca concentration in thermal waters.

It is noticeable that $\mathrm{CO}_{2}$-rich waters from the Kojuh area obey roughly the same $\mathrm{Ca}^{1 / 2} / \mathrm{K} v s$. $\mathrm{Na} / \mathrm{K}$ relationship; this is also true for the waters not very far from Kojuh: Levounovo and Sandanski which are intermediate between

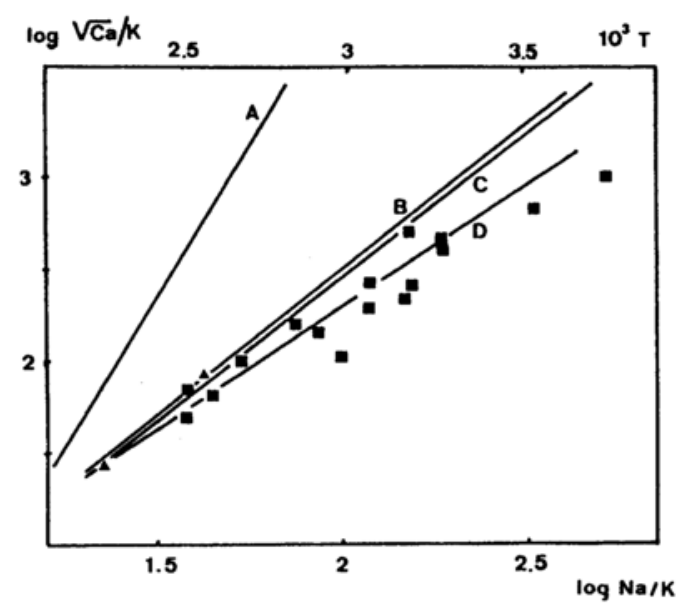

Fig. 10. $\sqrt{ } \mathrm{Ca} / \mathrm{K}$ vs. $\mathrm{Na} / \mathrm{K}$ relationship in Bulgarian waters. A. Fournier and Truesdell's relationship for $\beta=1 / 3$. B. Fournier and Truesdell's relationship for $\beta=$ 4/3. C. Relationship for Pyrénées and Corsica waters (Michard and Roekens, 1983). D. Best fitted line for Bulgarian waters.

alkaline and $\mathrm{CO}_{2}$ rich waters. On the contrary, any equibria involving $\mathrm{A} 1$ ions are verified neither at outflow temperature nor in any cooling simulation for $\mathrm{CO}_{2}$-rich waters. This suggests that dissolved species were evolved during the cooling either deviated from equilibrium or their evolution was controlled by a more complicated set of equilibria.

\section{CONCLUSION}

Arnorsson et al. (1983) have previously demonstrated that alkaline waters in basaltic environments of Iceland are approximately in equilibrium with some minerals common in hydrothermal assemblages, even at low temperatures of about $50^{\circ} \mathrm{C}$. In our study of Pyrénées and Corsica alkaline waters, we present a model suggesting that the equilibria are also approximately reached for waters from granitic environments in the temperature range of $60-140^{\circ} \mathrm{C}$.

Different methods for simulating the evolution of the chemical composition of waters with change in temperature were presented (Michard and Fouillac, 1980; Fritz, 1981; Michard and Roekens, 1983; Reed and Spycher, 1984). In models developed by our group, continuous 
reequilibration of the cooled waters with some minerals is taken in acount. Especially, from observed equilibrium between water and kaolinite at outflow temperature (Michard et al., 1979), we assumed without any evidence that this equilibrium was achieved in the deep reservoir and maintained through cooling processes.

Bulgarian hot alkaline waters from drillholes in a granic area provide a unique set of samples for a tentative confirmation of hypotheses assumed in our model for alkaline hot waters. Nine waters were sampled at equilibration temperature. It was confirmed that the equilibria seem to have been reached with minerals such as chalcedony (or quartz), albite, adularia, calcite, kaolinite and presumably a calcium zeolite. Chemical geothermometry seems to be useful at temperatures as low as $40^{\circ} \mathrm{C}$. Nevertheless, a small degree of under- or supersaturation can yield errors of about $\pm 25^{\circ} \mathrm{C}$ for the $\mathrm{Na} / \mathrm{K}$ and $\pm 15^{\circ} \mathrm{C}$ for the chalcedony thermometers.

Comparison between the nine waters sampled at equilibration temperature and the seven waters outflowing after cooling suggests that aluminum, contrary to silica, sodium or potassium, is deposited during cooling. Waters of the two groups are both in equilibrium with kaolinite. This indicates that one of the major assumptions of our model for alkaline waters is realistic. Any calculation of chemical changes associated with cooling of waters which does not take into account aluminum deposition (Reed and Spycher, 1984) yields erratic results.

\section{REFERENCES}

Arnorsson, S. (1975) Application of the silica geothermometers in low temperature hydrothermal areas in Iceland. Am. J. Sci. 275, 763-784.

Arnorsson, S., Sigurdsson, S. and Svavarsson, H. (1983) The geochemistry of geothermal waters in Iceland. II. Mineral equilibria and independent variables controlling water compositions. Geochim. Cosmochim. Acta 47, 547-566.

Bastide, J. P. (1985) Etude géochimique de la nappe du Dogger du Bassin Parisien. Thèse de Spécialité Université Paris 7.

Boulègue, J., Fouillac, C., Michard, G. and Quzounian,
G. (1977) Applications géothermiques de l'étude géochimique des eaux thermales des Pyrénées Orientales. Seminar on Geothermal Energy. EUR 5920. 2, 455-466.

Boulègue, J., Ciabrini, J. P., Fouillac, C., Michard, G. and Ouzounian, G. (1979) Dosage des espèces du soufre dans les eaux thermales réductrices: Géochimie des eaux de Puzzichello (Corse). Chem. Geol. 25, 19-36.

Boulègue, J., Fouillac, C. and Michard, G. (1981) Dépôts minéraux à l'emergence des sources thermales sulfurées sodiques des Pyrénées Orientales. Bull. Miner. 104, 661-668.

Brooks, C. A., Mariner, R. H., Mabey, D. R., Swanson, J. R., Guffanti, M. and Muffler, L. J. P. (1978) Hydrothermal convections systems with reservoir temperature $>90^{\circ}$. Assessment of Geothermal Resources of the United States. U. S. Geol. Surv. Cìrcular 790, 18--85.

Couturier, Y., Michard, G. and Sarazin, G. (1984) Constantes de formation de complexes hydroxydés de l'aluminium en solution aqueuse de 20 à $70^{\circ} \mathrm{C}$. Geochim. Cosmochim. Acta 48, 649-659.

De Carvalho, A. (1955) Estudios analiticos de aguas termais. Dir. Gen. Mines, Service Geol. 74-175.

Ellis, A. J. (1970) Quantitative interpretation of chemical characteristics of geothermal systems. Geothermics Spec. Issue No. 2, 2, 516-528.

Fancelli, R. and Nuti, S. (1978) Studio geochemico delle sorgenti termali del massiccio cristallino dell'Argentera (Alpi Marittime). Boll. Soc. Geol. Ital. 19, 115-130.

Fouillac, C. and Michard, G. (1981) Sodium/lithium ratio in water applied to geothermometry of geothermal reservoirs. Geothermics 10, 55-70.

Fournier, R. O. and Truesdell, A. H. (1973) An empirical Na-K-Ca geothermometer for natural waters. Geochim. Cosmochim. Acta 37, 1255-1275.

Fritz, B. (1981) Etude thermodynamique et modélisation des réactions hydrothermales et diagénétiques. Mem. Sci. Geol. No. 65, 197p.

Grimaud, D. (1986) Géochimie des eaux thermominérales des Alpes Françaises. Thèse Université Paris 7.

Grimaud, D., Huang, S., Michard, G. and Zheng, K. (1985) Chemical study of geothermal waters of Central Tibet (China). Geothermics 14, 35-48.

Helgeson, H. C., Delany, J., Nesbitt, W. H. and Bird, K. D. (1978) Summary and critique of the thermodynamic properties of rock forming minerals. Am. J. Sci. 278A, 1-229.

Mahon, W. A. J. (1975) Review of hydrogeochemistry of geothermal systems. Proc. 2nd Symp. on Development and Use of Geothermal Resources. San Francisco. 1, 775-783. 
Maruyama, S., Lion, J. G. and Cho, M. (1983) Experimental investigation of heulandite-laumontite equilibrium. Ext. Abstr. 4th Int. Symp. Water-Rock Interaction. Misasa, Japan. 305-308.

Michard, G. (1967) Signification du potentiel rédox dans les eaux naturelles. Mineral. Deposita 2, 34-36.

Michard, G. (1979) Géothermomètres chimiques. Bull. B. R. G. M., Ser. II, 2, 183-189.

Michard, G. (1983) Recueil de données thermodynamiques concernant les équilibres eaux-minéraux dans les réservoirs hydrothermaux. Rapport Commission des Communautes Européennes. EUR 8590 FR.

Michard, G. (1985) Equilibres entre minéraux et solutions géothermales. Bull. Miner. 108, 29-44.

Michard, G. and Fouillac, C. (1980) Contrôle de la composition chimique des eaux thermales sulfurées sodiques du Sud de la France. Géochimie des Interactions entre les Eaux, les Minéraux et les Roches, Edited by Y. Tardy, 147-166.

Michard, G. and Roekens, E. (1983) Modelling of the chemical composition of alkaline hot water. Geothermics 12, 161-169.

Michard, G., Fouillac, C., Grimaud, D. and Denis, J. (1981) Une méthode d'estimation des températures des réservoirs alimentant les sources thermales. Exemple du Massif Central Français. Geochim. Cosmochim. Acta 45, 1199-1207.

Michard, G., Ouzounian, G., Fouillac, C. and Sarazin, G. (1979) Contrôle des concentrations d'aluminium dissous dans les eaux thermales. Geochim. Cosmochim. Acta 43, 147-155.

Morris, J. C. and Stumm, W. (1967) Redox equilibria and measurements of potential in the aquatic environment. Equilibrium Concepts in Natural Waters Systems. Adv. Chem. Ser. 67, 270-285.

Nazarenko, V. A. and Nevskaia, E. M. (1969) Détermination spectrophotométrique des constantes d'hydrolyse des ions aluminium. Russ. J. Inorg. Chem. 14, 1696-1704.

O'Nions, K., Oxburgh, R. K., Hilton, D., Hill, R. and
Fouillac, C. (1985) Preliminary studies of ${ }^{3} \mathrm{He} /{ }^{4} \mathrm{He}$ ratio in thermal waters from the French Massif Central. Submitted to Nature.

Oxburgh, R. K., and O'Nions, K. (1984) Helium Isotopes in Geothermal Systems. Report Contract EG A 3004 UK (N).

Pentcheva, E. N. and Petrov, P. S. (1969) La composition gazeuse et microchimique des eaux minérales et les phenomènes volcaniques récents dans la Bulgarie du Sud Ouest. Proc. 5ème Congr. Int., A. I. T. I., Agnano Terme. 123-136.

Petrov, P. S. (1960) Observations géologiques et hydrogéologiques sur la région du volcan éteint de kojuh, Bulgarie du Sud-Ouest. Trav. Géol. Bulgarie, Ser. Stratigr. Tect. No. 1, 195-205.

Reed, M. and Spycher, J. (1984) Calculation of pH and mineral equilibria in hydrothermal waters with application to geothermometry and study of boiling and dilution. Geochim. Cosmochim. Acta 48, 1749-1792.

Sumi, K. (1975) Catalogue of Hot Springs and Mineral Springs in Japan. Geological Survey of Japan. 134p.

Tonani, F. (1980) Geochemistry in geothermal investigation. Advances in European Geothermal Research, March 1980, Strasbourg. Oral communication.

Truesdell, A. H. (1975) Geochemical techniques in Exploration Proc. 2nd U. N. Symp. Development and Use of Geothermal Resources Vol. 1, p.LII-LXXIX.

Vandelanoote R. (1984) Trace element geochemistry in thermal waters (E. Pyienees). Thesis, University of Anvers, 489 pp.

Vuataz, F. D. (1982) Hydrogéologie, géochimie et géothermie des eaux thermales de Suisse et des régions alpines limitrophes. Matériaux pour la Géologie de la Suisse 29, 1-174.

Vuataz, F. D., Criaud, A. and Fouillac, C. (1985) Les eaux thermales sulfurées de la Principauté d'Andorre. Rapport B. R. G. M. in prep.

White, D. E. (1965) Saline water of sedimentary rocks. Am. Assoc. Petroleum Geologists Mem. 4, 342-366. 